\title{
The efficient use of small plots in a fynbos phytosociological study in the northern Cederberg: a quick way to collect plant-environmental data
}

\author{
P.J. MUSTART*, E.J. MOLL* and H.C. TAYLOR**
}

Keywords: Cederberg, phytosociological survey, small plot sizes

ABSTRACT

\begin{abstract}
A phytosociological survey of selected plant communities in the northern Cederberg was made using small $\left(4-16 \mathrm{~m}^{2}\right)$ plot sizes. A satisfactory phytosociological table was obtained, and plant-environmental relationships were inferred from it. The use of small plot sizes enabled ecological information about plant communities to be quickly. easily and efficiently obtained. This method could be of considerable use for establishing and monitoring vegetation patterns.
\end{abstract}

\section{UITTREKSEL}

'n Fitososiologiese opname van geselekteerde plantgemeenskappe in die noordelike Cederberg is gemaak, en klein (4-16 $\mathrm{m}^{2}$ ) perseelgroottes is gebruik. 'n Bevredigende fitososiologiese tabel is verkry, en plant-omgewingsverhoudings is daaruit afgelei. Die gebruik van klein perseelgroontes het daartoe gelei dat ekologiese inligting oor plantgemeenskappe vinnig, maklik en doeltreffend verkry kon word. Hierdie metode sou heel nuttig vir die bepaling en monitering van plantegroeipatrone gebruik kon word.

\section{INTRODUCTION}

The Zürich-Montpellier, or Braun-Blanquet, approach has been widely used to survey and classify vegetation (Werger 1974). The aim of such studies is to describe the communities of the chosen area and to correlate them with environmental factors. In South Africa these vegetation studies have been carried out at scales ranging from regional, comprising several thousands of hectares (Boucher 1978; Cowling 1984: Taylor 1984), to smaller areas of a few hundred hectares and less (Werger et al. 1972; Cowling et al. 1976: Campbell \& Moll 1977: McKenzie et al. 1977; Glyphis et al. 1978; Laidler et al. 1978; Campbell et al. 1980; Van Wilgen \& Kruger 1985). In these studies plot size has ranged from 4 to $200 \mathrm{~m}^{2}$ : choice of plot size has largely depended on floristic richness and structure of the communities sampled, and usually ignores the smallscale pattern. Relatively small plots (e.g. $25 \mathrm{~m}^{2}$ ) have been suggested as suitable for reflecting less habitat heterogeneity than larger plot sizes, in turn leading to the unmasking of subtle variations within the observed communities (Van Wilgen \& Kruger 1985).

Large plots possibly covering heterogeneous habitats and hence reflecting transitional communities, are timeconsuming for data collection. Small plots obviate both these problems. The aim of this study was to perform a phytosociological survey in the northern Cederberg using plots of small size $\left(4-16 \mathrm{~m}^{2}\right)$ in order to see if a satisfactory Braun-Blanquet table could be obtained, and if plantenvironmental patterns could be inferred.

\footnotetext{
* Department of Botany. University of Cape Town. Private Bag, Rondebusch 77(), Cape Town.

**y Dorries Drive, Simonstown 7995.

MS. received: 1992-198-17
}

STUDY AREA

The area surveyed was in the Pakhuis Pass area of the northem Cederberg at altitudes ranging from 600 to 1000 $\mathrm{m}$. The communities sampled lay between $18^{\circ} 59^{\prime} \mathrm{E}$ to $19^{\circ} 04^{\prime} \mathrm{E}$, and $32^{\circ} 08^{\prime} \mathrm{S}$ to $32^{\circ} 11^{\prime} \mathrm{S}$, covering an area of approximately 300 hectares. The vegetation is described as Mesic Mountain Fynbos (Moll et al. 1984). The geology of the area is quartzitic sandstone of the Peninsula Formation of the Table Mountain Group. The area falls within the $60 \%$ winter rainfall region. The annual rainfall is $480 \mathrm{~mm}$ of which $72 \%$ falls between April and August (winter). Mean monthly maximum temperatures range from $20^{\circ} \mathrm{C}$ (winter) to $30^{\circ} \mathrm{C}$ (summer). Mean minimum temperatures drop to $5^{\circ} \mathrm{C}$ in midwinter.

\section{METHODS}

The area was surveyed using aerial photographs in order to broadly identify communities. Braun-Blanquet techniques as described by Werger (1974) were used. Since plant relationships with the environment, and with other plants, will be related to both the scale of environmental variation and to plant size, relevé size was chosen in relation to vegetation structure (height) as follows: $2 \times$ $2 \mathrm{~m}(<1 \mathrm{~m}$ in height); $2 \times 4 \mathrm{~m}(1-2 \mathrm{~m}$ in height $)$; and 4 $\times 4 \mathrm{~m}$ ( $>2 \mathrm{~m}$ in height). The following data were collected in January 1986: floristic lists and cover abundance for each of five to six relevés per community ( 22 plots in total): species not in the relevé, but occurring in the surrounding area in a $1-2 \mathrm{~m}$ border round the plot recorded as $(+)$. Environmental data, as set out in Table 1, were recorded for each relevé. The computer program TWINSPAN (two-way indicator species analysis, Hill 1979) was applied to the raw data. producing a tabular matrix approximating Braun-Blanquet table work. The matrix was further sorted by hand. 
TABLE 1.-Phytosociological table of northern Cederberg communities

Height of tallest stratum $(\mathrm{m})$ Plot size $\left(\mathrm{m}^{2}\right)$

Rock cover (superscripts are BB cover values)

Aspect

Soil depth

Soil moisture

Slope

Altitude (m)

Number of species

Relevé

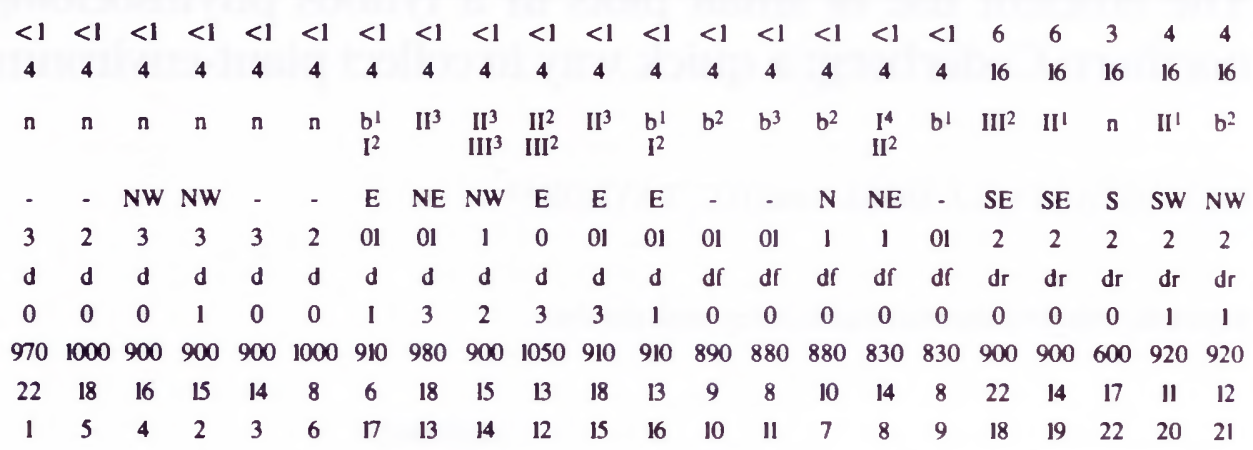

Community 1

Thamnochortus platypteris

Willdenowia arescens

Ischyrolepis monanthos

Macrostylis decipiens

Metalasia agathosmoides

Aristea sp.

Thesium sp. (H.T.10759)

Rafnia diffusa

Ficinia dunensis

Ischyrolepis sp. (cf. curviramis)

Pentaschistis viscidula

Muralia sp. (H.T.11380)

Ficinia bulbosa

Grisebachia ciliaris

Phaenocoma sp.

Campanulaceae (H.T.1086I)

Helichrysum sp.

Thymelaeaceae

Tetraria nigrovaginata

Mesembnanthemum sp.

Pelargonium sp.

Thesium nudicaule

Ursinia sp.

Elytropappus sp. (H.T.909/4)

Subcommunity $2 b$

Cannomois parviflora

Anthospermum aethiopicum

Tetraria ustulata

Ficinia deusta

Metalasia densa

Cymbopogon marginatus

Chasmanthe sp.

Tetraria cuspidata

Clutia alatemoides

Elytropappis sp.

Hypodiscus neesi

Pentaschistis curvifolia

Struthiola ciliata

Selago sp.

Campanulaceae

\section{Subcommunity 2a}

Ischyrolepis gaudichaudiana

Merxmuellera arundinacea

Community 2

Ischyrolepis sieberi

Sloebe plumosa

Ficinia nigrescens

Cliffortia ruscifolia

Lohostemon glaucophyllus

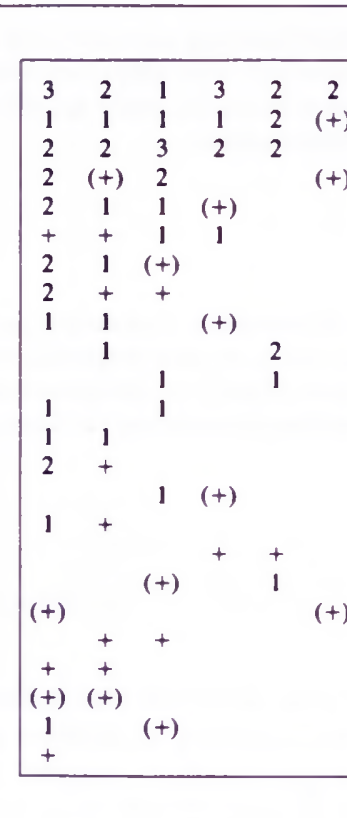

Subcommunity 3b

Indigofera frutescens

Pentaschistis sp.

Lidbeckia quinqueloba

Rhus rimosa

1

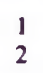

1

(t)

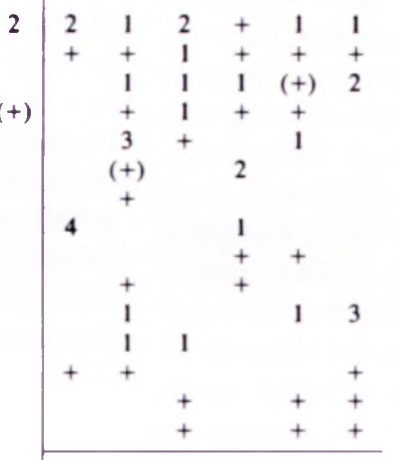

BB cover values: $(+)=$ not in quadrat, but occurring in surmunding area in a 1 to $2 \mathrm{~m}$ border round plot; $+=\langle 1 \%$ of quadrat area; $1=1-5 \%$; $2=5-25 \% ; 3=25-50 \% ; 4=50-75 \% ; 5=75-100 \%$.

Rock cover (superscripts are BB cover values) : $\mathrm{n}=$ none; $\mathrm{b}=$ bedmck; III $=$ rock size $(\mathrm{ht}),>0.5 \mathrm{~m} ; \mathrm{II}=0.25-0.5 \mathrm{~m} ; \mathrm{I}=0.05-0.25 \mathrm{~m}$.

Soil depth: $0=$ skeletal, $<0.05 \mathrm{~m} ; 1=$ shallow, $0.05-0.15 \mathrm{~m} ; 01=$ mixed skeletal and shallow; $2=$ medium, $0.15-1.00 \mathrm{~m} ; 3=$ deep, $>1.0 \mathrm{~m}$.

Soil moisture: $\mathrm{d}=\mathrm{dry}$, well drained; $\mathrm{df}=\mathrm{dry}$, flat, hard surface; $\mathrm{dr}=\mathrm{dry}$, well drained with runoff.

Slope: $0=$ level, $0-3^{\circ} ; 1=$ gentle, $4-8^{\circ} ; 2=$ moderate, $9-16^{\circ} ; 3=$ steep, $17-26^{\circ}$ 
TABLE 1.-Phytosociological table of northern Cederberg communities (continued)

\begin{tabular}{|c|c|c|c|c|c|c|c|c|c|c|c|c|c|c|c|c|c|c|c|c|c|c|}
\hline Height of tallest stratum (m) & $<1$ & $<1$ & $<1$ & $<1$ & $<1$ & $<1$ & $<1$ & $<1$ & $<1$ & $<1$ & $<1$ & $<1$ & $<1$ & $<1$ & $<1$ & $<1$ & $<1$ & 6 & 6 & 3 & 4 & 4 \\
\hline Plot size $\left(\mathrm{m}^{2}\right)$ & 4 & 4 & 4 & 4 & 4 & 4 & 4 & 4 & 4 & 4 & 4 & 4 & 4 & 4 & 4 & 4 & 4 & 16 & 16 & 16 & 16 & 16 \\
\hline $\begin{array}{l}\text { Rock cover (superscripts are } \\
\text { BB cover values) }\end{array}$ & $\mathrm{n}$ & $\mathrm{n}$ & $n$ & $\mathrm{n}$ & $\mathbf{n}$ & $\mathrm{n}$ & $\begin{array}{l}b^{\prime} \\
l^{2}\end{array}$ & II $^{3}$ & $\begin{array}{l}\mathrm{II}^{3} \\
\mathrm{III}^{3}\end{array}$ & $\begin{array}{l}\text { II }^{2} \\
\text { III }^{2}\end{array}$ & $\mathrm{II}^{3}$ & $\begin{array}{l}b^{1} \\
I^{2}\end{array}$ & $b^{2}$ & $b^{3}$ & $b^{2}$ & $\begin{array}{l}I^{4} \\
I^{2}\end{array}$ & $b^{\prime}$ & III $^{2}$ & II ${ }^{1}$ & n & II $^{1}$ & $b^{2}$ \\
\hline Aspect & - & - & NW & NW & - & - & $E$ & NE & NW & $\mathbf{E}$ & E & $\mathbf{E}$ & - & - & $\mathbf{N}$ & NE & - & SE & SE & s & sw & NW \\
\hline Soil depth & 3 & 2 & 3 & 3 & 3 & 2 & 01 & 01 & 1 & 0 & 01 & 01 & 01 & 01 & 1 & 1 & 01 & 2 & 2 & 2 & 2 & 2 \\
\hline Soil moisture & d & d & d & d & d & d & d & d & d & d & d & d & $\mathrm{df}$ & $d f$ & df & $\mathrm{df}$ & df & $\mathrm{dr}$ & $\mathrm{dr}$ & $\mathrm{dr}$ & $\mathrm{dr}$ & $d r$ \\
\hline Slope & 0 & 0 & 0 & 1 & 0 & 0 & 1 & 3 & 2 & 3 & 3 & 1 & 0 & 0 & 0 & 0 & 0 & 0 & 0 & 0 & 1 & I \\
\hline Altitude (m) & 970 & 1000 & 900 & 900 & 900 & 1000 & 910 & 980 & 900 & 1050 & 910 & 910 & 890 & 880 & 880 & 830 & 830 & 900 & 900 & 600 & 920 & 920 \\
\hline Number of species & 22 & 18 & 16 & 15 & 14 & 8 & 6 & 18 & 15 & 13 & 18 & 13 & 9 & 8 & 10 & 14 & 8 & 22 & 14 & 17 & lI & 12 \\
\hline Relevé & 1 & 5 & 4 & 2 & 3 & 6 & 17 & 13 & 14 & 12 & 15 & 16 & 10 & 11 & 7 & 8 & 9 & 18 & 19 & 22 & 20 & 21 \\
\hline
\end{tabular}

Subcommunity 3 a

Myrsine africana

Chironia baccifera

Diospyros glabra

Phylica oleifolia

Euclea acutifolia

Viscum sp.

Rhus undulata

Community 3

Olea europaea subsp. africana

Mavenus oleoides

Heeria argentea

Euclea natalensis

Ficinia acuminata

Protasparagus scandens

Protea nitida

\section{Widespread species}

Eriocephalus africanus

Ehrharia ramosa
$(+)$

2

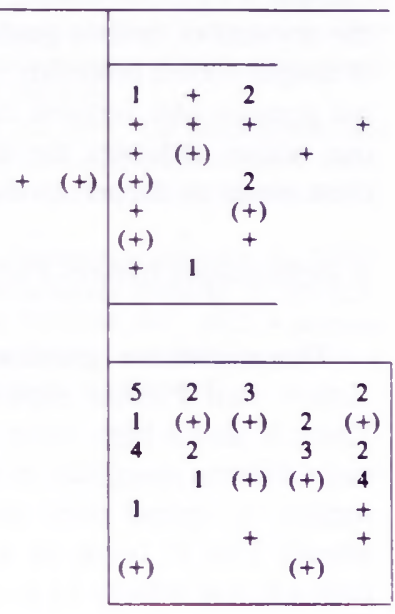

$(+)$

BB cover values: $(+)=$ not in quadrat, but occurring in surmunding area in a 1 to $2 \mathrm{~m}$ horder round plot; $+=\langle 1 \%$ of quadrat area; $1=1-5 \%$; $2=5-25 \% ; 3=25-50 \% ; 4=50-75 \% ; 5=75-100 \%$.

Rock cover (superscripts are BB cover values) : $\mathrm{n}=$ none; $\mathrm{b}=$ bedrock; III $=$ mak size (ht), $>0.5 \mathrm{~m}$; II $=0.25-0.5 \mathrm{~m} ; \mathrm{I}=0.05-0.25 \mathrm{~m}$.

Soil depth: $0=$ skeletal, $<0.05 \mathrm{~m} ; 1=$ shallow, $0.05-0.15 \mathrm{~m}$; $01=$ mixed skeletal and shallow; $2=$ medium, $0.15-1.00 \mathrm{~m} ; 3=$ deep, $>1.0 \mathrm{~m}$.

Soil moisture: $d=d r y$, well drained; $d f=d r y$, nat, hard surface; $d r=d r y$, well drained with runoff.

Sope: $0=$ level, $0-3^{\circ} ; 1=$ gentle, $4-8^{\circ} ; 2=$ moderate, $9-16^{\circ} ; 3=$ steep, $17-26^{\circ}$

Species not included in the above and found in one relevé only (species name is followed by relevé number, cover abundance value): Agathosma sp. 13, +; A. pubigeralesterhuyseniae 6,1 ; Arctotis laenis $1,(+) ;$ A. sp. 2,$2 ;$ Aspalathus spinosissima 8,$1 ;$ A. tridentata/quinquejolia 2 , $(+) ;$ Aristea singularis $20,+$ : Babiana sp. 8, 1; Cassine peragua 19, (+); Chrusocoma tenuifolia 22, (t); Crassula atropurpurea 9, +; Cullumia bisulca 8, 2; Dilatris ixioides 17, (t); Diosma acmaeophylla 9, (+); Diospyros austro-africana 19, 1: Dadonaea viscosa 22, +; Erica cf. articularis 7, +; Eriocephalus sp. 5, 1; Euclea linearis 22, 1; $E$. undulata 22, +; Ficinia cedarbergensis 15. (+); F. compar 5, 1; Gnidia sp. 3, 1; Helichrysum rutilans 3, +; Hpadiscus argenteus 15, 1; Kiggelaria africana 19. (+); Knowltonia capensis 22, +; Leucadendron concavum 1, +; Lobelia sp. 14, +; Macrostylis squarrosa 7, 2; Manulea sp. 3, (+); Maysenus heterophylla 22. 1; Muraltia sp. 16, +; Othonna amplexifolia 22, (+); Passerina glomerala 8, 1; Pelargonium cf. crithmoides 8, +; $P$. scabrum 12, I; Phanaceum sp. 2 , +; Podocarpus elongatus 19, 2; Prismatocarpus sp. 1, +; Protasparagus sp. 18, +; Protea acaulos 2, (+); Restio sp. (H.T. 00714) 6, 3; Rhus dissecia 22, (+); $\boldsymbol{R}$. scyophylla 19, +; R. tomentosa 18, 1; Scabiosa sp. 3, 1; Secamone alpinii 18. (+); Selago sp. 13, +; Serruria aitonii $2,(+)$; Sroebe sp. 4 , +.

\section{RESULTS AND DISCUSSION}

There are three major floristic communities (Table 1).

\section{Thamnochortus platypteris-Willdenowia arescens Community}

This community is an open herbland occurring in relevés 1 to 6. and differential species are Thamnochortus platypteris and Willdenowia arescens. This graminoid guild is further represented by high cover of Ischyrolepis monanthos in all relevés except number 6 (which in general has few species): as well as Ficinia dunensis in three relevés; and Ischyrolepis cf. curviramis, Pentaschistis viscidula. Tetraria nigmvaginata and Ficinia bulbosa in two relevés each. Macrostylis decipiens and Rafnia diffusa are low sprawling bushes ( $\pm 300 \mathrm{~mm}$ high), together forming an understorey to the restioid stratum in three relevés. Metalasia agathosmoides occurs in four relevés, and there is an occasional low presence of further asteraceous species, Phaenocoma sp., Helichnisum sp., Elytropappus sp. and Ursinia sp., in some of the relevés.

This community occurs on flat, sandy plains that are fully exposed to sun and wind. The soil is well drained 
and deep ( $>1 \mathrm{~m}$ in four relevés, and $0.15-1.00 \mathrm{~m}$ in two relevés), and consists of a coarse-textured pale grey sand. There is no rock cover. These factors, together with the hot, dry summers and low annual rainfall create generally very dry conditions.

The widespread and generally high cover of Restionaceae species substantiates the hypothesis that these shallow-rooted species are suited to survive in areas exposed to severe summer drought due to their ability to respond to summer moisture flushes with very rapid photosynthesis (Van der Heyden \& Lewis 1989). The presence of both graminoids and Asteraceae concurs with Campbell's (1986) finding that these taxa predominate at the dry end of fynbos gradients. The occasional presence of deeper-rooted proteoids (Leucadendron concavum. Protea acaulos and Serruria aitonii), each occurring in only one relevé, indicates the infrequent availability of sufficient water at deeper levels.

\section{Ischyrolepis sieberi-Ficinia nigrescens Community}

This mid-dense graminoid shrubland has Ischyrolepis sieberi and Ficinia nigrescens as differential species. There is also a high cover of the shrubs Stoebe plumosa and Cliffortia ruscifolia, in many of the relevés. This community is spread over two different landscape forms: relevés 7 to 11 occur on level areas with much exposed bedrock, and relevés 12 to 17 occur on well-drained rocky slopes (gentle to steep). Both environments have soils varying in depth from skeletal to shallow, and consisting of dark brown, mixed fine and coarse sand particles. Soil of the bedrock environment type was dry and well drained when examined in mid-summer, but during winter rains the underlying bedrock could cause water accumulation. Soils on the rocky slopes would be well drained during the rainy season.

\section{Subcommunity $2 \mathrm{a}$}

This subcommunity of five relevés (7-11) on level bedrock has Ischyrolepis gaudichaudiana as sole differential species. Mer.muellera arundinacea occurs in two relevés.

\section{Subcommunity $2 b$}

This subcommunity occurs in the six relevés (12-17) of the rocky slopes environment, and has Cannomois parviflora and Anthospermum aethiopicum as differential species. Other graminoid species such as Tetraria ustulata. T. cuspidata and Ficinia deusta commonly occur as do the shrubby components Metalasia muricata and Struthiola ciliata. Within sight of each relevé was a mature Protea nitida and/or $P$. laurifolia forming a sparse woodland overstorey. The aspect of these slopes is mostly east with the one northwest-facing relevé (No. 14) being near to a seepage area. This, together with the high rock cover. would make it a less dry and less wind-exposed environment than the bedrock one, and could account for the absence of most of this subcommunity's species in the level bedrock environment (relevés 7-11). Furthermore, the rockiness in combination with slope-related drainage patterns would result in a variety of moisture-related microhabitats. This could also be the cause of the greater numbers of species found on the rocky slopes than on the level bedrock. Greater species richness on rocky slopes than on level areas in arid areas has been attributed to these factors (Barbour \& Diaz 1973; Olsvig-Whittaker et al. 1983).

\section{Olea europaea subsp. africana-Maytenus oleoides Community}

The differential species of this closed woodland are Olea europaea subsp. africana and Mavtenus oleoides. These, as well as Heeria argentea and Euclea natalensis, are common to most of the relevés of subcommunities $3 \mathrm{a}$ and $3 \mathrm{~b}$. This community occurs adjacent to large boulders ( $4 \mathrm{~m}$ and higher) which provide shelter from wind, sun and fire, as well as extra moisture due to shade and water runoff. Soils are of medium depth and the slope level to gentle. This has allowed the development of a closed woodland of trees and shrubs. Cassine peragua, a forest tree (in one relevé, No. 19), and Protasparagus scandens, common in forest undergrowth, indicate the tendency of succession to low forest. Substantial forest development in this community is undoubtedly limited by the low rainfall of the area. and the fact that the prevalence of fire on the adjacent plains severely limits the forest area.

\section{Subcommunity $3 \mathrm{a}$}

The differential species are Myrsine africana and Chironia baccifera in this subcommunity which occurs in three relevés. These, together with Diospyros glabra and Euclea acutifolia form an understorey to the closed woodland canopy. The ground layer is poorly developed and consists of sparsely occurring Chironia baccifera. These species are mostly excluded from the drier subcommunity $3 b$.

\section{Subcommunity $3 b$}

Indigofera frutescens and Pentaschistis sp. are differential species. This subcommunity represents a drier gradient of Community 3 since the relevés in which it occurs (20 and 21) have more sunny aspects ( $S W$ and NW) than the other relevés which face $\mathrm{S}$ or $\mathrm{SE}$. This could account for the absence of most of these species in the former subcommunity, and vice versa. These two subcommunities appear to reflect moisture-related microhabitat differences within the woodland community.

\section{CONCLUSIONS}

A satisfactory phytosociological table was produced using small plot sizes. We obtained a neat phytosociological table, with well-defined communities. This in itself indicates the existence of small-scale pattern in fynbos. The survey was quickly (five days field work) and easily achieved. The efficiency of this method would allow comparatively easy monitoring and quick establishment of plant-environmental relationships.

\section{ACKNOWLEDGEMENTS}

We thank P. Masson for assistance in using computer programs, and Prof. R.M. Cowling for commenting on the manuscript. 


\section{REFERENCES}

BARBOUR. M.G. \& DIAZ. D.V. 1973. Larrea plant communities on bajada and moisture gradients in the United States and Argentina. Vegetatio 28: 335-352.

BOUCHER. C. 1978. Cape Hangklip area II. The vegetation. Bothalia 12 455-497.

CAMPBELL. B.M. 1986. Montane plant communities of the Fynbos Biome. Vegetatio 66: 3-16.

CAMPBELL, B., GUBB, A. \& MOLL, E. 1980. The vegetation of the Edith Stephens Cape Flats Flora Reserve. Journal of South African Botany 46: 435-444.

CAMPBELL, B.M. \& MOLL, E.J. 1977. The forest communities of Table Mountain. South Africa. Vegetatio 34: 105-115.

COWLING, RM. 1984. A syntaxonomic and synecological study in the Humansdorp region of the Fynbos Biome. Bothalia 15: 175-227.

COWLING, R.M., MOLL. E.J. \& CAMPBELL. B.M. 1976. The ecological status of the understorey communities of pine forests on Table Mountain. South African Forestrn Journal 99: 13-24.

GLYPHIS, J., MOLL. E. \& CAMPBELL. B. 1978. Phytosociological studies on Table Mountain, South Africa. 1. The Back Table. Joumal of South African Botany 44: 281-289.

HILL. M.O. 1979. TWINSPAN-a FORTRAN pmgramme for arranging multivariate data in ordered two-way tables by classification of individuals and attributes. Section of Ecology and Systematics, Cornell University, Ithaca. New York.

LAIDLER. D., MOLL. E.J., CAMPBELL. B.M. \& GLYPHIS. J. 1978. Phytosociological studies on Table Mountain. South Africa. 2. The Front Table. Journal of South African Botany 44: 291295.
MCKENZIE. B.. MOLL. E.J. \& CAMPBELL. B.M. 1977. A phytosociological study of Orange Kloof, Table Mountain, South Africa. Vegetatio $34:$ 41-53.

MOLL. E.J., CAMPBELL. B.M., COWLING. R.M., BOSSI, L., JARMAN, M.L. \& BOUCHER. C. 1984. A description of major vegetation categories in and adjacent to the Fynbos Biome. South African National Scientific Programmes Report No. 83.

OLSVIG-WHITTAKER. L., SHACKAK. M. \& YAIR. A. 1983. Vegetation patterns related to environmental factors in a Negev Desert watershed. Vegetatio 54: 133-145.

TAYLOR. H.C. 1984a. A vegetation survey of the Cape of Good Hope Nature Reserve. 1. The use of Association Analysis and BraunBlanquet methods. Bothalia 15: 245-258.

TAYLOR, H.C. 1984b. A vegetation survey of the Cape of Good Hope Nature Reserve. 2. Descriptive account. Bothalia 15: 259291 .

VAN DER HEYDEN, F. \& LEWIS. O.A.M. 1989. Seasonal variation in photosynthetic capacity with respect to plant water status of five species of the mediterranean climate region of South Africa. South African Journal of Botany 55: 509-515.

VAN WILGEN. B.W. \& KRUGER. F.J. 1985. The physiography and vegetation communities of the Zachariashoek catchments; southwestern Cape Province. South African Joumal of Botany 51: $379-399$.

WERGER. M. 1974. On concepts and techniques applied in the ZuirichMontpellier method of vegetation survey. Bothalia 11: 309-323.

WERGER. M.J.A.. KRUGER, F.J. \& TAYLOR, H.C. 1972. A phytosociological study of the Cape Fynbos and other vegetation at Jonkershoek. Stellenbosch. Bothalia 10: 599-614. 
